\title{
БЛИЖНЕСРОЧНЫЙ ПРОГНОЗ ПО РАЗВИТИЮ ПОЛИТИЧЕСКОЙ СИТУАЦИИ В УКРАИНЕ
}

\begin{abstract}
Аннотация: Несмотря на то, что майдан 2.0 фактически выполнил поставленные перед собой задачи, а именно, свергнул Януковича, долгожданную стабильность и нормализацию обстановки в стране это не принесло.В результате необдуманной внутренней политики руководства страны, политическая напряженность в стране усилилась, территориальная целостность нарушена. Страна находится на грани гражданской войны, экономической катастрофы, дальнейшей утраты челостности и потери суверенитета. В этой связи актуализируется анализ политических процессов протекающих в стране, поиску линий разлома среди политической элиты и населения страны. Уже сейчас можно обозначить линию территориального разлома страны. Украина, исторически, со дня своей независимости была поделена на Запад и Восток. Во-первых, это обусловлено культурно-историческим фактором. Так Западные области Украины были в составе Речи Посполитой, а потом и Австро-Венгрии, как например Львовская, Ивано-Франковская и Тернопольская области. В результате чего, сформировался совершенно иной цивилизационный тип. В то время как некоторые ЮгоВосточные области в составе Украины относительно недавно. Во-вторых, данное противоречие усиливается и тем, что Восток более развит в промышленном отношении. И в основном, все объекты промышленности направленны на российский рынок, что было обусловлено экономической моделью СССР, экономическим райнированием ,в рамках которого каждый регион Советского Союза производил определенный продукт для внутреннего рынка страны. За годы независимости Украины промышленность так и не была переориентирована на другие рынки. В-третьих, в качестве одного из факторов территориального разлома страны выступают культурные и родственные связи. На Востоке Украине традиционны более тесные культурные и родственные связи с Россией, в частности, с приграничными территориями, в результате чего любые ухудшения отношения с Россией воспринимается крайне болезненно.
\end{abstract}

Ключевые слова: международные отношения, внешняя политика, Россия, Украина, политическая нестабильность, политический режим, государство, нация, безопасность, конфликт.

3 а годы независимости также появились новые факторы, которые усугубили территориальный раскол страны.

Во-первых, благодаря бездействию службы безопасности Украины были созданы комфортные условия для формирования и развития праворадикальных организаций на Западе Украины. Так с 1990 года на Украине начали появлятся различные праворадикальные организации. Первой в 1990 году была создана организация «УНА-УНСО» ${ }^{1}$, чьи боевики воевали в Карабахе, Приднестровье, Абхазии, Чечне, Косово и Южной Осетии ${ }^{2}$, где они получали ценный боевой опыт, денежные средства и оружие. В 1993 году была создана организация «Тризуб» ${ }^{3}$, предшественник появившегося позже «Правого Сектора». В 1999 году лидером данной

\footnotetext{
1 http://una-unso.in.ua/about/

2 Там же.

3 http://politbyro.in.ua/part/746-trizub-imeni-stepanabandery-patrioty-terroristy.html
}

организации стал Дмитрий Ярош ${ }^{4}$, руководитель «Правого Сектора». Ими были созданы устойчивые бандформирования по военному принципу и тренировочные лагеря на Западе Украины. Эти организация также активно занимались празднованием дней памяти Бандеры, Шухевича и других пособников нацистов во время Великой Отечественной войны, что естественно не могло не вызвать отторжение на юго-востоке Украины. Во-вторых, одним из факторов усиливших раскол, стали заигрывания государства с праворадикальными организациями. Так, звание Герой Украины было присвоено Роману Шухевичу (прим.ав-командующему УПА) ${ }^{5}$, а также его сыну Юрию Шухевичу6 ${ }^{6}$ создателю и ли-

\footnotetext{
4 Там же.

УКАЗ ПРЕЗИДЕНТА УКРАИНЫ № 965/2007 «О присвоении Р.Шухевичу звания Герой Украины» от 12 октября 2007 года

6 УКАЗ ПРЕЗИДЕНТА УКРАИНЫ № 703/2006 «О присвоении Ю.Шухевичу звания Герой Украины» от 19 августа 2006 года.
} 
деру УНА-УНСО. Помимо этого, президент Украины Ющенко также присвоил звание Героя Украины и Бандере. Правда, при Януковиче это награждение было отменено судом с формулировкой «не являлся гражданином Украины». Более того, на Западе страны были установлены памятники Бандере и Шухевичу. В ряде городов Западной Украины были названы улицы в честь бойцов дивизии СС «Галичина» (прим.ав. - на Нюрнбергском трибунале СС была признана преступной организацией). Ветераны этой дивизии, как и УПА во Львове, были приравнены к ветеранам ВОВ и получают дополнительные социальные надбавки ${ }^{8}$. В-третьих, необходимо также отметить отсутствие сформированной, взвешенной и последовательной политики, как внешней, так и внутренней. Во внешней и внутренней политике Украины можно выделить определенные циклы. К примеру, при Кравчуке вектор внутренней политики был смещен на Запад страны, так он поддержал создание Украинской Православной церкви Киевского Патриархата. Президентство Кучмы можно характеризовать смещением внутренней политики на Восток, как раз при нем начался приход к власти Виктора Януковича, которого он сделал премьер-министром. Президентство Ющенко можно снова охарактеризовать перегибом в сторону Западных областей Украины, началась реабилитация украинских пособников нацистских преступников и так далее, о чем упоминалось выше. Президентство Януковича же можно охарактеризовать, как попытку «усидеть на двух стульях». Вкратце, правление Януковича можно оценить постоянным метанием между Россией и ЕС. B-четвертых, начиная с 1990-х годов на Украине произошло, две так называемые «революции», основу которых составляли, как правило, выходцы с Западной Украины. Естественно, в этих условиях противоречия и недопонимания между Западом и Востоком только крепло, так как «неработающий» Запад Украины навязывал свои идеалы и ценности «работающему» Востоку и, по сути, малая часть народа Украины решала за всю страну как жить и куда дальше двигаться.

Эти факторы обусловили раскол еще до событий евромайдана.

\footnotetext{
Донецкий суд отменил указ Ющенко о присвоении Бандере звания Героя. УНИАН от 02.04.2010.

8 Во Львове у ветеранов дивизии СС «Галичина» льготы стали больше, чем у воинов Советской армии. Эксперты говорят это повредит имиджу Украины. УНИАН от 17.04.2013.
}

События после евромайдана только усугубили дальнейшей раскол страны, это связано со следующими факторами.

1. Верховная Рада отменила закон о региональных языках, в результате чего в восточных областях вспыхнули массовые гражданские волнения, поэтому и.о Президента Турчинову пришлось наложить вето на эту отмену.

2. Новая власть в Киеве не идет на диалог с лидерами протестных движений на Востоке страны, объявляет их сепаратистами и уголовно преследует, в результате чего лидерам протестных движений не останется ничего другого как радикализироваться. Так было заведено уголовное дело на «народного губернатора» Донецка Губарева ${ }^{9}$, посажен под домашний арест бывший губернатор Харькова М.Добкин ${ }^{10}$. С одной стороны это лишает протест лидеров, но с другой радикализирует и озлобляет людей.

3. Верховная рада обязала государственные органы удалить русскоязычные версии своих сайтов до 10 марта, тем самым «подлив масла в огонь». ${ }^{11}$

4. Принятие условий МВФ. Новой власти Украины придется принять условия МВФ с целью получения экономической помощи, в результате будут подняты цены на газ для населения, урезаны социальные выплаты и сделаны другие непопулярные шаги. Учитывая, то что в Крыму ожидается рост социальных выплат, повышения зарплат, можно смело заявить, что эти шаги не найдут должной поддержки среди населения страны и приведут к росту недовольства населением страны.

5. Приказ о расформирования «Беркута» и преследовании силовиков. В результате этого популистского шага, сотрудникам «Беркута» не оставалось ничего другого как перейти на сторону лидеров протестного движения и отказываться подчиняться, как это было в Крыму. В результате этих действий новая украинская власть не может полностью рассчитывать на поддержку их политики силовиками в ЮгоВосточных регионах страны.

6. Губернаторы-олигархи и «правительство-победителей». Назначение губернаторов-оли-

\footnotetext{
9 Донецк: как арестовали «народного губернатора» Губарева. ВВС Русская служба от 09.03.2014.

10 Киевский суд отправил Добкина под домашний арест. Интерфакс от 11.03.2014.

11 Госорганы Украины должны будут удалить русскоязычные версии сайтов. РИА Новости от 07.03.2014.
} 
гархов в Восточные области Украины не способствует успокоению регионов и еще больше радикализурует протестные настроение, как это происходит в Донецке или Днепропетровске. Также стоит упомянуть о формировании нового кабинета министров. Фактически новое правительство и и.о президента не пользуются популярностью у народа и представляют собой такую же коррумпированную и прогнившую власть, которая ими была свергнута.

7. Подписание соглашения ассоциации с ЕС. Премьер-министр Украины подписал политическую часть соглашения об ассоциации с ЕС, подписание экономической части отложено на время после выборов. Подписание экономической части соглашения сулит экономические проблемы Украине, так как Российская Федерация является важнейшим партнером Украины $25 \%$ экспорта и $32 \%{ }^{12}$ импорта приходится на Россию). Большая часть промышленности Украины ориентирована на российский рынок, потеря этого рынка приведет к росту безработице, падению финансового благополучия населения и как следствие росту недовольству.

8. Частичная мобилизация. Частичная мобилизация и переброска войск на Восток Украины воспринимается негативно местным населением, т.к людей заставляют подписывать контракты, а в случае отказа и попытки покинуть части, грозят уголовным преследованием ${ }^{13}$. Также были случаи воспрепятствия продвижению военной техники ${ }^{14}$, передислокации войск, вывозу вооружения и снаряжения со складов и ба $3^{15}$ на Юго-Восточной Украине.

9. Повышение цен на газ. В результате того, что Украина просрочила платежи по газу, скидка на газ будет отменена. Также Россия денонсировала Харьковские соглашения, в результате чего скидка в 100 долларов за 1000 кубических метров будет отменена. Премьер-министр Украины Яценюк заявил, что «Украина будет

\footnotetext{
12 https://www.cia.gov/library/publications/the-worldfactbook/geos/up.html

13 https://www.youtube.com/watch?v=uRtyaa976s4 https://www.youtube.com/watch?v=tY5eyMTce_I

14 Жители Луганска перекрыли дорогу, по которой идут эшелоны с техникой http://lifenews.ru/news/129142

15 Новое. Артёмовск, вывоз оружие из складов и конфликт с мирными жителями. 25.03.2014.

https://www.youtube.com/watch?v=OZH6uSMzSgU
}

платить любую цену за газ» ${ }^{16}$. Скорее всего Украину и Россию ожидает новая газовая война. Уже заявлено, что с 1 мая 2014 года цена на газ для населения возрастет на $50 \%,{ }^{17}$ естественно население страны вряд-ли воспримет такие меры положительно

10. Отсутствие единого лидера страны. В стране нет человека, который мог бы консолидировать всю страну в целом, как Восток и Запад, предстоящие выборы Президента вряд-ли способствует появлению такого лидера, в результате чего раскол между Востоком и Западом только будет возрастать.

11. В.Ф.Янукович. Нынешним законно избранным президентом страны является Янукович. В этой связи на Востоке Украины проходят митинги с лозунгами «Янукович наш президент» ${ }^{18}$. На мой взгляд, Янукович может заявить о себе до президентских выборов на Украине. Не смотря на то, что в результате его бездействия случился государственный переворот и его авторитет как никогда низок. Таким образом, Янукович еще может повлиять на политическую ситуацию на Украине, особенно на Юго-Востоке.

12. Долги. На данный момент задолженность Украины составляет около 26 млрд долларов США ${ }^{19}$. Однако эта сумма подсчитана без учета долга России, который составляет по заявлениям Медведева 16 млрд.долларов, а также долга Китаю, который составляют 3 млрд долларов и за который Китай готовится судиться.

13. Наемники. Появилась информация, что губернаторы Днепропетровска и Донецка подали идею и.о президенту Турчинову, привлечь для подавления протестных настроений на Востоке страны иностранных наемников. Это свидетельствуют о следущем: во-первых, местным органам правопорядка не доверя-

\footnotetext{
16 Яценюк: цена российского газа с апреля может вырасти до \$500 http://economics.unian.net/energetics/899476-yatsenyuktsena-rossiyskogo-gaza-s-aprelya-mojet-vyirasti-do-500.html

17 Газ для населения в Украине с 1 мая подорожает на 50\% http://economics.unian.net/energetics/900865-gaz-dlyanaseleniya-v-ukraine-s-1-maya-podorojaet-na-50.html

18 Митингующие в Донецке и Одессе просят Януковича вернуться на Украину Read more: http://www.ntv.ru/ novosti/867376/\#ixzz2x3XITdSM

19 Украине в этом году не хватает для выживания почти 300 млрд гривень http://economics.unian.net/finance/901132ukraine-v-etom-godu-ne-hvataet-dlya-vyijivaniya-pochti-300mlrd-griven.html
} 


\section{Международные отношения / International Relations}

ют; во-вторых ,в случае более массовых акций протеста возможен полный переход силовых структур на сторону народа ${ }^{20}$.

Резюмируя все вышесказанное, можно сделать ряд выводов. Во-первых, на данный момент ЮгоВосток Украины проигрывает борьбу с самопровозглашённой властью по причине арестов лидеров протеста, т.к это приводит к обезглавливанию протестного движения. Во-вторых, протестные движения на Юго-Востоке были спонтанными и стихийными, они не были заранее подготовлены и организованы, отсутствует сценарий и план действий. В-третьих, если проанализировать митинги на Юго-Востоке страны, можно отметить такую особенность, как проведение протестных движений по выходным дням(прим.авт. 1-2 марта, 8-9 марта, 15-16 марта, 22-23 марта). Это означает, что большинство протестующих работают в будние дни, «профессиональных» протестующих там нет. Также стоит отметить, из-за действий украинских пограничников сочувствующие люди из приграничных областей не имеет возможности оказать поддержку протестующим. Следовательно, протест на Юго-Востоке Украины имеет потенциал в будущем, так как в результате действий новых властей ухудшения экономической ситуации на Украине «не за горами». Это обусловлено с помощью МВФ, ухудшением отношений с РФ, повышением цен на газ ,потенциальным подписанием экономической части соглашения с ЕС, в результате чего льготы для украинских товаров на российском рынке и рынке Таможенного Союза будут отменены, а промышленность окажется неконкурентоспособной. Также стоит отметить и тот факт, что Украина находится в долгах, это около 6 млрд.долларов России (прим. авт - Дмитрий Медведев заявил о 16 млрд долларов ${ }^{21}$ ), также должна 3 млрд долларов Китаю, (Пекин заявил о намерении судиться с Киевом ${ }^{22}$ ). В-четвертых, экономика Украина фактически находится в преддефолотном состоянии, становится ясным, что ответственность ляжет тяжким бременем на население, что в свою очередь, особенно на фоне повышения социальных

20 Источник в СБУ: Подавлением протестов на востоке Украины займутся западные наемники http://vz.ru/ news/2014/3/25/678766.html?utm_campaign=vz\&utm_ medium $=$ referral\&utm_source $=$ newsanons

21 Украина должна России 16 млрд долларов - Дмитрий Медведев. Подробности: http://www.regnum.ru/news/1781299. html\#ixzz2x3yYCOcJ Любое использование материалов допускается только при наличии гиперссылки на ИA REGNUM

22 http://www.gazeta.ru/business/2014/02/26/5927513.shtml выплат и зарплат в Крыму, может катализировать протестные настроения на Украине. В-пятых, необходимо отметить, что привлечение иностранных наемников свидетельствуют о низком уровне доверии правоохранительным органам со стороны новой власти и потенциальной возможности перехода силовиков на сторону народа, в случае более массовых, спланированных акций протеста. И в-шестых, потенциальную угрозу «революционерам» может составить и президент Украины Янукович, которого на митинга на востоке Украины призывают «вернутся и спасти народ».

\section{Анализ украинской власти и противоречий внутри неё}

Как известно «революция пожирает своих детей», как правило, протестные настроения сплачивают представителей разных политических взглядов. После прихода к власти оппозиции, они начинают делить власть и посты, к тому же из-за разных политических идеалов у них начинаются расхождения, что в свою очередь ведет к «зачисткам» среди еще вчерашних сторонников. Так было в революционной Франции, в России, так же было и на Украине после майдана 2004 года, когда еще вчерашние сторонники и борцы за «свободу» Ющенко и Тимошенко переругались между собой. Так и происходит и будет происходит сейчас на Украине.

Безусловно, основным врагом «бандитской хунты» является «Правый Сектор». Это обусловливается, тем, что бойцы Правого Сектора отказались войти в состав Национальной Гвардии ${ }^{23}$, так как они хорошо вооружены, в том числе тяжелым вооружением(прим. авт. - ПЗРК «Игла»), дисциплинированны, имеют боевой опыт и филиалы по всей Украине и самое главное, не подчиняются никому кроме своих руководителей. Именно бойцы «Правого Сектора» были на острие атаки во время событий евромайдана, именно они фактически обеспечили захват власть. Также «Правый Сектор» известен одиозными выходками и высказываниями своих членов (Александр Музычко ${ }^{24}$, Дмитрий

\footnotetext{
23 «Правый сектор» отказался разоружаться и вступать в Нацгвардию http://www.newsru.com/world/18mar2014/ nodisarm.html

24 Сашко Билый Александр Музычко пришел на заседание с автоматом. http://www.youtube.com/watch?v=2kHwJW13TB0 Сашко Билый (Александр Музычко) разговаривает с прокурором (ПОЛНАЯ ВЕРСИЯ). http://www.youtube.com/ watch?v=g1NFNFkKuWc
} 
Ярош ${ }^{25}$ - прим. авт.). Такая одиозная организация вызывает массу вопросов, как в России, так и на Западе компрометирует новую власть. Естественно, в первую очередь, новой власти необходимо убрать данную организацию из сводок новостей и политической сцены, нейтрализовать её боевиков, т.к она представляет угрозу новой власти. Именно поэтому был ликвидирован и Александр Музычко, который по заявлению МВД Украины застрелился сам $^{26}$. На мой взгляд, это была спланированная спецоперация, целью которой было именно устранение, а не задержание данного человека. Также считается, что операцию разработали и спланировали в СБУ, а не в МВД. В качестве аргументов можно привести то, что лидеров протестных движений на Востоке задерживали СБУ, т.е. спецслужбы занимались арестами невооруженных людей, а задержание Музычко доверили МВД. По-моему мнению, возможно отстранение главы МВД от исполнение служебных обязанностей и перемещением на менее заметное место, но произойдет это только после того, как МВД нейтрализует угрозу «Правого Сектора» и других вооруженных боевиков, которые являются украинским аналогом штурмовых отрядов Эрнеста Рема $^{27}$. В качестве вектора направления зачисток можно определить «Правый сектор», т.к. Аваков пообещал продолжить бороться с «правым сектором и другими бандитами» ${ }^{28}$, устранение Сашко Билого (Александра Музычко - прим. авт) вписывается в этот сценарий, а после пикетирования Верховной Рады с требованием отставки и суда над министром МВД, появилась информация, что Аваков выступил с инициативой запретить «Правый Сектор».

В связи с убийством Музычко наиболее возможным мне кажется следующий сценарий. Дмитрий Ярош уже заявил, что будет добиваться отставки министра МВД Авакова и ареста всех силовиков, которые принимали участие в операции ${ }^{29}$. Вооружен-

25 СМИ: Лидер украинского «Правого сектора» попросил помощи у Доку Умарова. Оригинал статьи: http://russian. rt.com/article/23421\#ixzz2x4RRHerx

26 Информация о ходе расследования уголовного производства в отношении Александра Музычко. http://mvs.gov.ua/mvs/control/main/ru/publish/article/1007771

27 Дмитрий Ярош потребовал отставки главы МВД Украины Арсена Авакова

http://www.profile.ru/sobytiya/item/80503-dmitrij-yaroshpotreboval-otstavki-glavy-mvd-ukrainy-arsena-avakova

28 http://odessa.comments.ua/news/2014/03/25/174046.html

29 Пуля в теле Музычко была выпущена из оружия, которое находилось в его руке - МВД. http://www.unian.net/ ное противостояние не выгодно на данный момент Ярошу, так как он заявил о своем намерение баллотироваться на пост Президента страны и создал политическую партию «Правый Сектор». Верховная Рада уже создала комиссию при участие общественных организаций по изучению обстоятельств смерти Сашко Билого, которая вряд ли выявит чтото противоправное в действиях сотрудников милиции. Расследование данного инцидента растянется на неопределённое время, которое будет использовано скорее всего для организации аналога «ночи длинных ножей», так как лишившись руководства боевики «Правого сектора» вряд ли смогут оказать серьезное сопротивление.

Также скорее всего можно рассматривать следующую группу во власти, действующую сообща. Секретарь СНБО Парубий, председатель СБУ Наливайченко и председатель СВР Украины Гвоздь, также с секретарем СНБО Украины скорее всего имеет тесные связи и глава президентской администрации Сергей Пашинский. Так, он вывозил винтовку во время событий на Майдане ${ }^{30}$, что по заявлению бывшего председателя СБУ Якименко «невозможно было сделать без разрешения коменданта Майдана Парубия» ${ }^{31}$. Сергей Пашинский член Партии «Батькивщина» является руководителем Житомирской областной ячейки партии, предеседателем партии «Батькивщина» является Юлия Тимошенко.

Также членами Партии «Батькивщины» являются и.о президента Турчинов, премьер-министр Украины. Хотя они являются лишь исполнителями воли Тимошенко , их цель заключается в проведение непопулярных реформ, после которых у них не будет поддержки среди электората, они лишь обусловят приход к власти Юлии Тимошенко ,которая в данный момент не имеет достаточной поддержки населения. Так согласно опросам населения рейтинг Тимошенко составляет 13,1\%, третье место после Кличко $(14,8 \%)$ и Порошенко $(26,2 \%)^{32}$. На фоне этого рейтинга не случайно выглядят и

politics/901167-pulya-v-tele-muzyichko-byila-vyipuschena-izorujiya-kotoroe-nahodilos-v-ego-ruke-mvd.html

30 Депутат Пашинский вывозит с Майдана снайперскую винтовку https://www.youtube.com/watch?v=6b-gpzLHLPQ

31 Интервью с бывшим руководителем СБУ Александром Якименко. Просмотрено 13.03.2014 в 12.34 http://www. youtube.com/watch?v=P-QXXMQbyhE

32 В «Батькивщине» выяснили, что украинцы хотят видеть президентом страны «шоколадного» олигарха. Подробнее: http://www.rosbalt.ru/ukraina/2014/03/12/1243315.html 
заявление Тимошенко о том, что «на олигархии надо поставить крест», это сигнал для Порошенко о том, что если он пойдет на выборы, то будут последствия для него и для тех, кто его поддержит, а учитывая что в руках партии «Батькивщины» или людей связанных с ней сосредоточены основные посты страны - МВД, СНБОУ, СБУ, Порошенко вряд ли решится участвовать в выборах.

Также намечается потенциальный конфликт между партиями «УДАР» и «Батькивщина». 26 марта на заседании Верховной Рады Кличко критиковал Турчинова и заявил, что «если так будет продолжаться и впредь, мы можем поднять вопрос об отставке главы Верховной Рады» ${ }^{33}$. Рейтинг Кличко сейчас выше, чем у Тимошенко, поэтому Тимошенко постарается устранить Кличко из политической борьбы. В данный момент есть легальный способ, те кто собирается баллотироваться в президенты должен прожить 10 лет до выборов в стране, Кличко прожил меньше ${ }^{34}$. Также через подконтрольные олигарху телеканалы будет начата кампания по дискредитации Кличко. Следует отметить и заявление Тимошенко, в котором она назвала Верховную Раду «гадюшником, который надо менять на новый». Скорее всего она хочет ослабить влияние других партий в Раде и увеличить влияние «Батькивщины».

На данный момент партия «Удар» не представлена ни в кабинете министров, ни в других органах исполнительной власти республиканского значения. В кабинете министров посты занимают в основном представители «Батькивщины» и «Свободы», а также представители Майдана и беспартийные. Так, министр энергетики и угольной промышленности Юрий Продан был министром энергетики и топлива в правительстве Тимошенко, таким образом, он является «своим человеком» для Юлии Владимировны.

Скорее всего, министерских постов лишатся те люди, которые к профессиональному управления никогда не имели отношение и пришли на посты через Майдан, а именно Министр спорта и молодёжи Украины Дмитрий Булатов,министр здравоохранения Олег Мусий и министр экономического развития и торговли Павел Шеремета.

\footnotetext{
33 СМИ: Новая власть на грани раскола - Кличко поднял бунт против Турчинова. СМИ: Новая власть на грани раскола - Кличко поднял бунт против Турчинова

http://www.unian.net/politics/900770-smi-novaya-vlast-nagrani-raskola-klichko-podnyal-bunt-protiv-turchinova.html

34 Виталия Кличко остановит ценз оседлости http://izvestia.ru/news/559744
}

\section{Перспективы развития майдана 3.0}

Уже сейчас в социальных сетях в группах «Правый сектор», «Евромайдан» и других, так или иначе принимавших и освещавших события на Майдане, появляются призывы к организации нового майдана, требования люстрации, а также непринятие Украиной «утилизационного сбора ${ }^{35}$ » и других требований.

28 марта состоялось пикетирование около Верховной Рады, в котором участвовало до 2000 человек. На мой субъективный взгляд, попытки организации нового майдана в ближайшей перспективе обречены на провал по следующим причинам:

1. Отсутствие спонсоров. Любая революция всегда требует денег,так было во время Октябрьской революции, майдана 2004 года, майдана 2013-2014 года. Организаторам вряд ли стоит рассчитывать на какую-либо финансовую помощь. Большинство украинских олигархов Коломойский, Тарута, Порошенко и другие так или иначе аффилированы с государством и вряд ли выступят спонсорами. Иностранные государства тоже не будут спонсировать новый переворот, так как к власти пришли люди,которые их устраивают и которым они готовы оказать финансовую поддержку. Без финансовой поддержки протестующие обречены на провал.

2. Отсутствие специалистов по «цветным» революциям. «Цветные» революции организуют и проводят специалисты, соответствующие технологи, которые так или иначе либо аффилированы с иностранными спец.службами, либо являются их сотрудниками, естественно, такую поддержку никто не будет оказывать новому майдана.

3. Отсутствие подконтрольных СМИ. У новых протестующих отсутствуют им подконтрольные СМИ, без них они не смогут освещать «правильно» ситуацию и формировать нужный им информационный фон. Теоретически, российские каналы могли бы освещать эти события в нужном русле, но на большинстве территории Украины они запрещены.

4. Отсутствие поддержки среди Западных политиков. Среди западных официальных лиц они вряд ли найдут поддержку, поэтому на международ-

\footnotetext{
35 Несколько сот человек продолжают митинговать под ВР http://www.unian.net/politics/901275-neskolko-sot-chelovekprodoljayut-mitingovat-pod-vr.html
} 
ным уровне их действия будут восприняты негативно. Потенциальный разгон нового майдана не будет осужден никем из Западных стран, действия власти получат одобрение и поддержку.

Резюмируя, можно сказать, что попытки организация нового майдана скорее всего в ближайшей перспективе (прим. ред. - 1-3 месяца) обречены на провал, т.к как не будет массовой поддержки населения, нет спонсоров, а также отсутствует информационная поддержка, нет специалистов по организации данных акций, а также нет необходимого финансирования.

Резюмируя все вышесказанное, можно сделать следующие выводы. Во-первых, народу Украины предстоит ухудшение экономического положения. Это связано с повышением цен на газ Газпромом, принятие условий МВФ, тяжелым экономическим положение Украины. Во-вторых, протестные настроения, как и на Востоке, так и на Западе страны, имеют потенциал для роста, хотя скорее всего будут жестко пресекаться новой властью. В случае синхронных народных волнениях в большинстве регионах страны, теоретически возможно повторения «крымского» сценария. В-третьих, ликвидация руководства «Правого Сектора» неизбежна. «Правый сектор» представляют опасность для новой украинской власти, поэтому ликвидация руководства и нейтрализации угрозы этой орга- низации станет первочередной задачей нового руководства страны. Убийство Сашко Билого можно считать началом данной политики. Скорее всего Украину ждет «ночь длинных ножей», так как вооруженные неконтролируемые боевиков являются мощным дестабилизирующим фактором, который может поставить под вопрос территориальную целость Украины и её суверенитет, появление очагов нестабильности и вмешательства Вооруженных сил России. В-четвертых, можно констатировать тот факт, что люди Тимошенко контролируют деятельность государства, занимают основные ключевые посты в государстве. Тимошенко уже заявила о намерение участвовать в президентских выборах на Украине 25 мая, в этой связи ёё главными конкурентами является Кличко и Порошенко. Порошенко не заявил о своем намерение участвовать в президентских выборах и вряд ли изменит свое решение. Поэтому главной целью Тимошенко и её окружение станет ослабления влияние партии «Удар» и её лидера Виталия Кличко. В-пятых, уже сейчас на митингах на Юго-Востоке Украины появляются лозунги с просьбой к легитимному Президенту Украины Януковичу «защитить народ». В этой связи возможно возвращение Януковича на Украину и перехода ряда Юго-Восточных регионов под его контроль, хотя стоит отметить что это сценарий маловероятен.

\section{Библиография}

1. Задорожнюк Э. Г. Украина как «ось консолидации» в 1990-х годах // Регионы и границы Украины в исторической ретроспективе : сборник. - Москва, 2004.

2. http://politbyro.in.ua/part/746-trizub-imeni-stepana-bandery-patrioty-terroristy.html

3. УКАЗ ПРЕЗИДЕНТА УКРАИНЫ № 965/2007 «О присвоении Р.Шухевичу звания Герой Украины» от 12 октября 2007 года

4. УКАЗ ПРЕЗИДЕНТА УКРАИНЫ № 703/2006 «О присвоении Ю. Шухевичу звания Герой Украины» от 19 августа 2006 года.

5. Донецкий суд отменил указ Ющенко о присвоении Бандере звания Героя. УНИАН от 02.04.2010.

6. Во Львове у ветеранов дивизии СС «Галичина» льготы стали больше, чем у воинов Советской армии. Эксперты говорят - это повредит имиджу Украины. УНИАН от 17.04.2013.

7. Донецк: как арестовали «народного губернатора» Губарева. ВВС Русская служба от 09.03.2014

8. Киевский суд отправил Добкина под домашний арест. Интерфакс от 11.03.2014

9. Госорганы Украины должны будут удалить русскоязычные версии сайтов. РИА Новости от 07.03.2014

10. https://www.cia.gov/library/publications/the-world-factbook/geos/up.html

11. https://www.youtube.com/watch?v=uRtyaa976s4

12. https://www.youtube.com/watch?v=tY5eyMTce_I

13. Жители Луганска перекрыли дорогу, по которой идут эшелоны с техникой http://lifenews.ru/news/129142

14. Новое. Артёмовск, вывоз оружие из складов и конфликт с мирными жителями. 25.03.2014. https:// www.youtube.com/watch?v=0ZH6uSMzSgU

15. Яценюк: цена российского газа с апреля может вырасти до \$500http://economics.unian.net/ energetics/899476-yatsenyuk-tsena-rossiyskogo-gaza-s-aprelya-mojet-vyirasti-do-500.html 
16. Газ для населения в Украине с 1 мая подорожает на 50\% http://economics.unian.net/energetics/900865gaz-dlya-naseleniya-v-ukraine-s-1-maya-podorojaet-na-50.html

17. Митингующие в Донецке и Одессе просят Януковича вернуться на Украину http://www.ntv.ru/ novosti/867376/\#ixzz2x3XITdSM

18. Украине в этом году не хватает для выживания почти 300 млрд гривен http://economics.unian.net/ finance/901132-ukraine-v-etom-godu-ne-hvataet-dlya-vyijivaniya-pochti-300-mlrd-griven.html

19. Источник в СБУ: Подавлением протестов на востоке Украины займутся западные наемники http:// vz.ru/news/2014/3/25/678766.html?utm_campaign=vz\&utm_medium=referral\&utm_source=newsanons

20. Украина должна России 16 млрд долларов-Дмитрий Медведев Подробности: http://www.regnum.ru/ news/1781299.html\#ixzz2x3yYCOcJ Любое использование материалов допускается только при наличии гиперссылки на ИА REGNUM

21. http://www.gazeta.ru/business/2014/02/26/5927513.shtml

22. “Правый сектор" отказался разоружаться и вступать в Нацгвардию http://www.newsru.com/ world/18mar2014/nodisarm.html

23. Сашко Билый Александр Музычко пришел на заседание с автоматом . http://www.youtube.com/ watch?v=2kHwJW13TB0

24. Сашко Билый (Александр Музычко) разговаривает с прокурором (ПОЛНАЯ ВЕРСИЯ). http://www. youtube.com/watch?v=g1NFNFkKuWc

25. СМИ: Лидер украинского «Правого сектора» попросил помощи у Доку Умарова Оригинал статьи: http://russian.rt.com/article/23421\#ixzz2x4RRHerx

26. Информация о ходе расследования уголовного производства в отношении Александра Музычко. http://mvs.gov.ua/mvs/control/main/ru/publish/article/1007771

27. Дмитрий Ярош потребовал отставки главы МВД Украины Арсена Авакова http://www.profile.ru/ sobytiya/item/80503-dmitrij-yarosh-potreboval-otstavki-glavy-mvd-ukrainy-arsena-avakova

28. http://odessa.comments.ua/news/2014/03/25/174046.html

29. Пуля в теле Музычко была выпущена из оружия, которое находилось в его руке - MBД http://www. unian.net/politics/901167-pulya-v-tele-muzyichko-byila-vyipuschena-iz-orujiya-kotoroe-nahodilos-v-egoruke-mvd.html

30. Депутат Пашинский вывозит с Майдана снайперскую винтовку https://www.youtube.com/watch?v=6bgpzLHLPQ

31. Интервью с бывшим руководителем СБУ Александром Якименко. Просмотрено 13.03.2014 в 12.34 http://www.youtube.com/watch?v=P-QXXMQbyhE

32. В «Батькивщине» выяснили, что украинцы хотят видеть президентом страны “шоколадного” олигарха Подробнее: http://www.rosbalt.ru/ukraina/2014/03/12/1243315.html

33. СМИ: Новая власть на грани раскола-Кличко поднял бунт против Турчинова http://www.unian.net/ politics/900770-smi-novaya-vlast-na-grani-raskola-klichko-podnyal-bunt-protiv-turchinova.html

34. Виталия Кличко остановит ценз оседлости http://izvestia.ru/news/559744

35. Несколько сот человек продолжают митинговать под ВP http://www.unian.net/politics/901275neskolko-sot-chelovek-prodoljayut-mitingovat-pod-vr.html

36. Манойло А.В. Технологии управления политическими конфликтами в революциях на Ближнем Востоке и в Северной Африке. Политэкс (Политическая экспертиза), 8(1):131-154, 2012.

37. Манойло А.В. Цветная революция в Сирии: что дальше? .//Национальная безопасность. - 2011. № 6. - C.150-151.

38. Manoylo A.V. “Color Revolution”: Armed Rebellion in Ukraine LAST Wake-up CALL to Russia? [Электронный pecypc] / The 4-th Media. Beijing: Thursday, March 6, 2014, 12:55. Код доступа: URL: http://www.4thmedia. org/2014/03/06/armed-rebellion-in-ukraine-could-be-the-last-wake-up-call-to-russia/ (дата обращения 30.03.2014)

39. Манойло А.В. Вооруженный мятеж в Украине может стать для России последним тревожным звонком // NB: Международные отношения. — 2014. - № 2. - C.24-37. DOI: 10.7256/2306-4226.2014.2.11137. URL: http://e-notabene.ru/wi/article_11137.html

40. Манойло А.В. Интересы внешней политики США в Афганистане. // Национальная безопасность/nota bene. - 2012. - №3. - C. 76-81. 
41. Спиридонов В.В. Экономические причины политического конфликта на Украине // NB: Международные отношения. - 2014. - 4. - C. 45-78. DOI: 10.7256/2306-4226.2014.4.11528. URL: http://www.enotabene.ru/wi/article_11528.html

42. Гушер А.И. Политический кризис на Украине // NB: Международные отношения. - 2014. - 3. - С. 1526. DOI: 10.7256/2306-4226.2014.3.11502. URL: http://www.e-notabene.ru/wi/article_11502.html

43. Бочарников И.В. Украинский кризис как элемент пояса стратегического окружения России // NB: Международные отношения. - 2014. - 4. - C. 7-32. DOI: 10.7256/2306-4226.2014.4.11617. URL: http:// www.e-notabene.ru/wi/article_11617.html

44. Гушер А.И. Кризис на Украине: геополитические и геостратегические аспекты // NB: Международные отношения. - 2014. - 4. - C. 79-89. DOI: 10.7256/2306-4226.2014.4.11605. URL: http://www.e-notabene. ru/wi/article_11605.html

45. Манойло А.В. Вооруженный мятеж в Украине: волна цветных революций идет на Россию // NB: Международные отношения. - 2014. - 3. - C. 27-35. DOI: 10.7256/2306-4226.2014.3.11498. URL: http:// www.e-notabene.ru/wi/article_11498.html

46. Манойло А.В. Геополитическая картина современного мира // Национальная безопасность / nota bene. - 2013. - 5. - C. 149-155. DOI: 10.7256/2073-8560.2013.5.9394.

\section{References}

1. Zadorozhnyuk E. G. Ukraina kak «os' konsolidatsii» v 1990-kh godakh // Regiony i granitsy Ukrainy v istoricheskoi retrospektive : sbornik. - Moskva, 2004.

2. http://politbyro.in.ua/part/746-trizub-imeni-stepana-bandery-patrioty-terroristy.html

3. UKAZ PREZIDENTA UKRAINY № 965/2007 “O prisvoenii R.Shukhevichu zvaniya Geroi Ukrainy” ot 12 oktyabrya 2007 goda

4. UKAZ PREZIDENTA UKRAINY № 703/2006 O prisvoenii Yu. Shukhevichu zvaniya Geroi Ukrainy ot 19 avgusta 2006 goda.

5. Donetskii sud otmenil ukaz Yushchenko o prisvoenii Bandere zvaniya Geroya. UNIAN ot 02.04.2010.

6. Vo L'vove u veteranov divizii SS «Galichina» l'goty stali bol'she, chem u voinov Sovetskoi armii. Eksperty govoryat - eto povredit imidzhu Ukrainy. UNIAN ot 17.04.2013.

7. Donetsk: kak arestovali "narodnogo gubernatora" Gubareva. BBC Russkaya sluzhba ot 09.03.2014

8. Kievskii sud otpravil Dobkina pod domashnii arest. Interfaks ot 11.03.2014

9. Gosorgany Ukrainy dolzhny budut udalit' russkoyazychnye versii saitov. RIA Novosti ot 07.03.2014

10. https://www.cia.gov/library/publications/the-world-factbook/geos/up.html

11. https://www.youtube.com/watch?v=uRtyaa976s4

12. https://www.youtube.com/watch?v=tY5eyMTce_I

13. Zhiteli Luganska perekryli dorogu, po kotoroi idut eshelony s tekhnikoi http://lifenews.ru/news/129142

14. Novoe. Artemovsk, vyvoz oruzhie iz skladov i konflikt s mirnymi zhitelyami. 25.03.2014. https://www.youtube.com/watch?v=0ZH6uSMzSgU

15. Yatsenyuk: tsena rossiiskogo gaza $\mathrm{s}$ aprelya mozhet vyrasti do $\$ 500 \mathrm{http}: / /$ economics.unian.net/ energetics/899476-yatsenyuk-tsena-rossiyskogo-gaza-s-aprelya-mojet-vyirasti-do-500.html

16. Gaz dlya naseleniya v Ukraine s 1 maya podorozhaet na 50\% http://economics.unian.net/energetics/900865gaz-dlya-naseleniya-v-ukraine-s-1-maya-podorojaet-na-50.html

17. Mitinguyushchie v Donetske i Odesse prosyat Yanukovicha vernut'sya na Ukrainu http://www.ntv.ru/ novosti/867376/\#ixzz2x3XITdSM

18. Ukraine $\mathrm{v}$ etom godu ne khvataet dlya vyzhivaniya pochti $300 \mathrm{mlrd}$ griven http://economics.unian.net/ finance/901132-ukraine-v-etom-godu-ne-hvataet-dlya-vyijivaniya-pochti-300-mlrd-griven.html

19. Istochnik v SBU: Podavleniem protestov na vostoke Ukrainy zaimutsya zapadnye naemniki http://vz.ru/ news $/ 2014 / 3 / 25 / 678766 . h t m l$ utm_campaign=vz\&utm_medium=referral\&utm_source=newsanons

20. Ukraina dolzhna Rossii 16 mlrd dollarov-Dmitrii Medvedev Podrobnosti: http://www.regnum.ru/ news/1781299.html\#ixzz2x3yYCOcJ Lyuboe ispol'zovanie materialov dopuskaetsya tol'ko pri nalichii giperssylki na IA REGNUM

21. http://www.gazeta.ru/business/2014/02/26/5927513.shtml 
22. "Pravyi sektor" otkazalsya razoruzhat'sya i vstupat' v Natsgvardiyu http://www.newsru.com/ world/18mar2014/nodisarm.html

23. Sashko Bilyi Aleksandr Muzychko prishel na zasedanie s avtomatom . http://www.youtube.com/ watch?v=2kHwJW13TB0

24. Sashko Bilyi (Aleksandr Muzychko) razgovarivaet s prokurorom (POLNAYa VERSIYa). http://www.youtube. com/watch?v=g1NFNFkKuWc

25. SMI: Lider ukrainskogo «Pravogo sektora» poprosil pomoshchi u Doku Umarova Original stat'i: http://russian.rt.com/article/23421\#ixzz2x4RRHerx

26. Informatsiya o khode rassledovaniya ugolovnogo proizvodstva v otnoshenii Aleksandra Muzychko. http:// mvs.gov.ua/mvs/control/main/ru/publish/article/1007771

27. Dmitrii Yarosh potreboval otstavki glavy MVD Ukrainy Arsena Avakova http://www.profile.ru/sobytiya/ item/80503-dmitrij-yarosh-potreboval-otstavki-glavy-mvd-ukrainy-arsena-avakova

28. http://odessa.comments.ua/news/2014/03/25/174046.html

29. Pulya v tele Muzychko byla vypushchena iz oruzhiya, kotoroe nakhodilos' v ego ruke - MVD http://www.unian.net/ politics/901167-pulya-v-tele-muzyichko-byila-vyipuschena-iz-orujiya-kotoroe-nahodilos-v-ego-ruke-mvd.html

30. Deputat Pashinskii vyvozit s Maidana snaiperskuyu vintovku https://www.youtube.com/watch?v=6b-gpzLHLPQ

31. Interv'yu s byvshim rukovoditelem SBU Aleksandrom Yakimenko. Prosmotreno 13.03.2014 v 12.34 http:// www.youtube.com/watch?v=P-QXXMQbyhE

32. V "Bat'kivshchine" vyyasnili, chto ukraintsy khotyat videt' prezidentom strany "shokoladnogo" oligarkha Podrobnee: http://www.rosbalt.ru/ukraina/2014/03/12/1243315.html

33. SMI: Novaya vlast' na grani raskola-Klichko podnyal bunt protiv Turchinova http://www.unian.net/ politics/900770-smi-novaya-vlast-na-grani-raskola-klichko-podnyal-bunt-protiv-turchinova.html

34. Vitaliya Klichko ostanovit tsenz osedlosti http://izvestia.ru/news/559744

35. Neskol'ko sot chelovek prodolzhayut mitingovat' pod VR http://www.unian.net/politics/901275-neskolkosot-chelovek-prodoljayut-mitingovat-pod-vr.html

36. Manoilo A.V. Tekhnologii upravleniya politicheskimi konfliktami v revolyutsiyakh na Blizhnem Vostoke i v Severnoi Afrike. Politeks (Politicheskaya ekspertiza), 8(1):131-154, 2012.

37. Manoilo A.V. Tsvetnaya revolyutsiya v Sirii: chto dal'she? .//Natsional'naya bezopasnost'. - 2011. - № 6. S.150-151.

38. Manoylo A.V. “Color Revolution”: Armed Rebellion in Ukraine LAST Wake-up CALL to Russia? [Elektronnyi resurs] / The 4-th Media. Beijing: Thursday, March 6, 2014,12:55. Kod dostupa: URL: http://www.4thmedia.org/2014/03/06/ armed-rebellion-in-ukraine-could-be-the-last-wake-up-call-to-russia/ (data obrashcheniya 30.03.2014)

39. Manoilo A.V. Vooruzhennyi myatezh v Ukraine mozhet stat' dlya Rossii poslednim trevozhnym zvonkom // NB: Mezhdunarodnye otnosheniya. — 2014. - № 2. - S.24-37. DOI: 10.7256/2306-4226.2014.2.11137. URL: http://e-notabene.ru/wi/article_11137.html

40. Manoilo A.V. Interesy vneshnei politiki SShA v Afganistane. // Natsional'naya bezopasnost'/nota bene. 2012. - №3. - S. 76-81.

41. Spiridonov V.V. Ekonomicheskie prichiny politicheskogo konflikta na Ukraine // NB: Mezhdunarodnye otnosheniya. - 2014. - 4. - C. 45-78. DOI: 10.7256/2306-4226.2014.4.11528. URL: http://www.e-notabene. $\mathrm{ru} /$ wi/article_11528.html

42. Gusher A.I. Politicheskii krizis na Ukraine // NB: Mezhdunarodnye otnosheniya. - 2014. - 3. - C. 15-26. DOI: 10.7256/2306-4226.2014.3.11502. URL: http://www.e-notabene.ru/wi/article_11502.html

43. Bocharnikov I.V. Ukrainskii krizis kak element poyasa strategicheskogo okruzheniya Rossii // NB: Mezhdunarodnye otnosheniya. - 2014. - 4. - C. 7-32. DOI: 10.7256/2306-4226.2014.4.11617. URL: http://www.enotabene.ru/wi/article_11617.html

44. Gusher A.I. Krizis na Ukraine: geopoliticheskie i geostrategicheskie aspekty // NB: Mezhdunarodnye otnosheniya. - 2014. - 4. - C. 79-89. DOI: 10.7256/2306-4226.2014.4.11605. URL: http://www.e-notabene.ru/wi/ article_11605.html

45. Manoilo A.V. Vooruzhennyi myatezh v Ukraine: volna tsvetnykh revolyutsii idet na Rossiyu // NB: Mezhdunarodnye otnosheniya. - 2014. - 3. - C. 27-35. DOI: 10.7256/2306-4226.2014.3.11498. URL: http://www.enotabene.ru/wi/article_11498.html

46. Manoilo A.V. Geopoliticheskaya kartina sovremennogo mira // Natsional'naya bezopasnost' / nota bene. 2013. - 5. - C. 149-155. DOI: 10.7256/2073-8560.2013.5.9394. 